\title{
Cognitive Strategies for Dual Imperatives: EFL Listening and Speaking in Chinese Universities
}

\author{
Indika Liyanage \\ Griffith Institute for Educational Research, Griffith University, Australia \\ Brendan Bartlett \\ Australian Catholic University, Australia \\ Thomas Tao \\ Beijing Normal University at Zhuhai, People's Republic of China
}

\begin{abstract}
Strategic development of oral communication skills (i.e., listening and speaking) in English as a Foreign Language (EFL) in China is fraught with difficulties, including lack of contexts for authentic language use, examination-oriented pedagogy, and tacit educational practices. The quantitative study reported here was designed around a research question of how extensively three specific cognitive strategies translation, deduction, and contextualisation - are used when students are listening and speaking in class. It was conducted with a large sample $(N=1,440)$ of Chinese EFL learners at the tertiary level who were learning in class to speak and listen in English. Findings indicate all three strategies are used extensively in both modalities, but significantly more so in speaking. These findings are interpreted in relation to instructional objectives of preparing students for oral communication beyond the classroom and for passing the listening test in the College English Test Band 4 (CET-4).
\end{abstract}

The development of oral communication (listening and speaking) skills as opposed to the development of literacy (reading and writing) for English as a Foreign Language (EFL) learners in mainland China has been a slow and cumbersome process for both learners and teachers. Whilst factors such as limitations on access to resources and upgrading teachers' qualifications are constraining variables, most difficulties stem from lack of authentic contexts and purposes for oral language use, together with use of pedagogy which is culturally inappropriate within the Chinese educational tradition (see Anderson, 1993; Harvey, 1985; Rao, 2002; Y. Wang, 1991).

Multilingual communities usually present pragmatic reasons for authentic use of oral English as a medium of intracommunity communication. However, in non-English monolingual contexts such as China, typically there is no need for intracommunity communication in oral English. As a result,

Language Education in Asia, 2014, 5(1), 46-65. http://dx.doi.org/10.5746/LEiA/14/V5/I1/A05/Liyanage_Bartlett_Tao 
use of oral English has been limited mainly to language classrooms where learners are prepared for end-of-course examinations rather than for out-of-class contexts. Examination-oriented instruction also calls for heavy reliance on textbook-contrived linguistic accuracy. Hence, major focus has been on explicitly teaching and learning grammar (Rao, 2002).

The present study is one of several in a large ongoing research project between Australian and Chinese universities to examine the use of language learning strategies (LLS) by Chinese learners of English. The current research stems from one of the studies (Liyanage, Bartlett, Birch, \& Tao, 2012) which explored usefulness of strategies in developing listening and speaking skills as perceived by Chinese EFL learners. The authors extended the focus of that study by revisiting its data with specific interest in three language learning behaviours that are used typically by Chinese learners of English in developing oral communication skills in class. The three behaviours are relying on translation to and from Chinese in mediating meaning in oral English, attending to rules of grammar to deduce meaning when engaging in the use of oral English, and using context as an aid to meaning in the comprehension and production of oral English (see Barlow \& Lowe, 1985; Harvey, 1985; Maley, 1983; Scovel, 1983). These behaviours are well represented in the literature - for example, they correspond to the cognitive strategies of translation, deduction, and contextualisation respectively, as described by O'Malley and Chamot (1990, p. 137), and were used in their language learning strategy inventory. In the current study, use of these three cognitive strategies by Chinese EFL learners in university settings was investigated. How these strategies are realised in listening / speaking lessons for a regular class of freshmen and the effect of the use of these strategies on the College English Test Band 4 (CET-4) preparation classes is described in detail.

\section{Literature Review}

At the initial stages of LLS research, researchers relied on a macroskill framework (see for example, Oxford-Carpenter, 1985) to investigate the processes used by learners in learning second languages. The perception by most learners that the mastery of a language is the mastery of its macroskills and the process they use to master those (Bradshaw, 1974) aligns well with cognitive theories of learning (Bartlett, 2010). While metacognitive strategies address the broad, executive processes that learners adopt when attempting to acquire a language (Bartlett, 2010; Liyanage \& Bartlett, 2010, 2012; Liyanage, Grimbeek, \& Bryer, 2010), cognitive strategies address the specifics of language learning, such as its grammatical elements and how these are realised through macroskills at the more micro level. Consequently, it may be possible to plan metacognitively for a listening comprehension test because the test follows a standard format in patterning response. However, most listening is done in less structured and predictable formats than in test situations whether inside or outside the classroom. Thus, despite some conceivable advantage for test taking, it is no more possible to predict accurately (and therefore to prepare for) the detailed content of other listening comprehension events in the classroom than for those outside it.

Metacognitive strategies oversee language learning processes (Liyanage \& Bartlett, 2010; Liyanage et al., 2010), whereas cognitive strategies address specific demands of language learning, and social-affective strategies address interactivity processes in language learning. The use of taxonomies has been common in LLS research of which the Language Learning Strategy Inventory (LLSI) of Chamot, Kupper, and Impik-Hernandez (1987) is a good example. This LLSI had been framed to gather information about 16 strategies under metacognitive, cognitive and socialaffective headings when learning Spanish and Russian as foreign languages. However, additional 
interviews conducted by the same researchers found 10 extra strategies for which no questions had been framed. Subsequently, Liyanage (2004) adapted Chamot et al's (1987) LLSI to embrace the missing 10 strategies to investigate LLS use reported by Sri Lankan learners of ESL $(N=886)$. The strategies in the adapted LLSI are listed in Table 1. The adapted inventory was translated (see Appendix A for the English original used) into Chinese (Liyanage et al., 2012). It was the measure applied in the current study.

\section{Table 1}

Twenty-six Strategies in the Adapted LLSI (Liyanage, 2004)

\begin{tabular}{|c|c|c|}
\hline Metacognitive & Cognitive & Social Affective \\
\hline $\begin{array}{l}\text { Advanced Organisation } \\
\text { Organisational Planning } \\
\text { Directed Attention } \\
\text { Selective Attention } \\
\text { Self-monitoring } \\
\text { Self-evaluation } \\
\text { Self-management }\end{array}$ & $\begin{array}{l}\text { Repetition } \\
\text { Rehearsal } \\
\text { Resourcing } \\
\text { Translation } \\
\text { Grouping } \\
\text { Substitution } \\
\text { Note-taking } \\
\text { Summarising } \\
\text { Deduction } \\
\text { Imagery } \\
\text { Auditory Representation } \\
\text { Contextualisation } \\
\text { Elaboration } \\
\text { Transfer } \\
\text { Inferencing }\end{array}$ & $\begin{array}{l}\text { Questioning for Clarification } \\
\text { Cooperation } \\
\text { Self-talk } \\
\text { Self-reinforcement }\end{array}$ \\
\hline
\end{tabular}

Using LLSI surveys completed by 1,440 Chinese university students, Liyanage et al. (2012) found high frequency usage of selective attention, organisational planning and self-management, observing that these metacognitive strategies were favoured highly by students both in class and out of class. Notably, usage was significantly greater out of class. The authors explained these effects largely in terms of in-class preparation for the CET-4 listening test. The listening component of the CET-4 involved coaching for a highly predictable test format (see Appendix C), which may have affected students' strategy preferences related to their ideas about what are likely and possible as listening test items. In contrast, outside the classroom, students were faced with situations which were far broader in range, much less predictable - and often individually determined. It was considered that these out-of-class factors encouraged a more varied repertoire of strategies from which to draw adaptive responses. Associated with this was a high degree of washback into their ongoing learning, both within and outside class (see Lin, 2009; Shao, 2006).

\section{Washback}

Washback has long been recognised as a highly probable outcome of what Alderson and Wall (1993) termed high-stakes tests. For Chinese students and their teachers, national English tests at the end of secondary schooling, as well as at both undergraduate and postgraduate levels in tertiary 
education, are high-stakes tests. As undergraduates, they cannot graduate at bachelor's level without first passing the CET-4. Extremely large numbers of students are involved as this test is administered nationally, presenting logistical problems for conducting the speaking test in particular. Outcomes are such that now this macroskill is available on the CET only for those students who have scored better than $85 \%$ on the written test. As one would expect, the washback into university classrooms has resulted in considerably more emphasis on listening than on speaking. As Shao (2006) reported,

teaching activities in test-preparation classes mainly are centred on listening, reading and writing exercises, followed by translation, with the practice of speaking skills neglected. Although the curriculum stipulated attention to the five basic skills, speaking skills were not assessed in CET and the communicative approach existed in name only in this period. ... the skills taught and practiced in test preparation classes were solely those required in the test .... (p. 56)

Shao's (2006) comments refer to effects of CET-4 on classroom teaching in undergraduate programs at a typical university in China, specifically based on time given to various components of the ELT curriculum at different stages of students' progress through their programs. The study compared the time allocation in regular classes in students' first year with the allocation given to CET-4 preparation in their second (see Table 2).

\section{Table 2}

Class Time on Curriculum Components (Averages Based on Shao, 2006)

\begin{tabular}{|l|c|r|}
\hline \multicolumn{1}{|c|}{ Component } & $\begin{array}{c}\text { Regular Classes } \\
\left(1^{\mathrm{st}} \text { Year }\right)\end{array}$ & $\begin{array}{r}\text { Test-preparation Classes } \\
\left(2^{\text {nd }} \text { Year }\right)\end{array}$ \\
\hline Listening & $42 \mathrm{hr}(28.0 \%)$ & $45 \mathrm{hr}(31.4 \%)$ \\
\hline Speaking & $53 \mathrm{hr}(35.3 \%)$ & $0 \mathrm{hr}(0.0 \%)$ \\
\hline Reading & $48 \mathrm{hr}(32.0 \%)$ & $46 \mathrm{hr}(32.2 \%)$ \\
\hline Writing & $6 \mathrm{hr}(4.0 \%)$ & $34 \mathrm{hr}(23.8 \%)$ \\
\hline Translation & $1 \mathrm{hr}(0.7 \%)$ & $18 \mathrm{hr}(12.6 \%)$ \\
\hline Total & $150 \mathrm{hr}(100.0 \%)$ & $143 \mathrm{hr}(100.0 \%)$ \\
\hline
\end{tabular}

Similar data were reported in studies conducted at other Chinese universities (see Jin, 2008; W. Wang, 2010). Shao (2006) observed that "in the regular classes, the implementation of classroom teaching follows the College English Teaching Syllabus (1999) and The Requirements of College English Teaching (2004) without being influenced by CET" (p. 56). Such data reveal the pervasive effects of CET-4 preparation on what tertiary-level learners' EFL programs contain. In addition, those program components that remain are significantly influenced by the form that the testing takes in the CET-4. T. Tao (personal communication, April 7, 2011) reported on the teaching practices in a freshman English class and an interview with a teacher of a CET-4 preparation class (see Appendices B and C), which show a significant difference between language teaching and learning processes. It is to be expected, therefore, that use of language learning strategies will be affected by exposure to these different contexts.

The development of oral communication is complicated further by in-class preparation activities for nationwide high-stakes assessment tests which wash back on the pedagogy used by teachers 
and on the strategies their students adopt. For example, at tertiary levels, success in English language tests is crucial in the academic goals of Chinese students. They must pass the CET-4 to qualify for their bachelor's degree. However, in most cases, the CET-4 is designed to test only listening, reading and writing. The listening component, which currently is worth $35 \%$ of the total CET marks, is likely soon to be increased to $70 \%$ (T. Tao, personal communication, April 7, 2011). The situation has contributed largely to an examination-success orientation to learning and instruction rather than one of developing communicative skills for authentic interaction.

A considerable literature has addressed the influence of Confucian principles on current instructional practices in China in which two particular issues are prominent: the relationship between the teacher and the taught and the exposition of what knowledge is and how it should be imparted, learnt, assessed and evaluated (see Cortazzi \& Jin, 1996; Peng, 2007; Rao, 2002; Tan, 2008). At the level of specific techniques, rote learning and memorisation of content, together with an emphasis on reproducing it at examinations, play a major role in current Chinese educational practice. Whilst these emphases are encouraged actively in the teaching and learning of all subjects in the curriculum, it is widely acknowledged that success in English involves a dual focus: success in an examination and success in communication beyond the classroom. This places specific demands on both teachers and students, given that examination success depends on accuracy of usage in test tasks together with test-taking strategies that may involve processes at odds with those needed for mastery of authentic discourse. Therefore, this quantitative study was designed around the research question of how extensively the cognitive strategies of translation, deduction, and contextualisation are used by Chinese EFL learners at the tertiary level when listening and speaking in class.

\section{Method}

Participants in the study were a large sample $(N=1,674)$ of non-English majors in CET preparation classes from three universities in China. After a brief explanation (Chinese and English) of the scope and purpose of the study by a bilingual research assistant in each university, the LLSI was administered to students in class. Respondents took approximately 45-50 minutes to answer the questionnaire. After data cleaning, 1,440 complete data sets remained. Of these, $35.1 \%(n=506)$ were from male participants, $64.9 \%(n=935)$ were from females. Participants were between 18 20 years of age and had studied English for 9-11 years.

The adapted LLSI (Liyanage, 2004; Liyanage et al., 2012) was used in the current study (see Table 3 , alpha coefficient levels ( $>0.5$ ), for reliability statistics). Participants used a four-point Likert response scale (always to never) to rate how often they utilised the behaviours described in each item. Items illustrating each of the three targeted cognitive behaviours (strategies) are:

Translation: I find myself translating what the teacher says back into Chinese so I can understand.

Deduction: When listening to the teacher, I apply grammar rules to help myself understand.

Contextualisation: When I learn a new word, I say it in a sentence as soon as possible. 
Table 3

Reliability Statistics for the Three Scales

\begin{tabular}{|l|c|c|}
\hline \multicolumn{1}{|c|}{ Scale } & No. of Items & Cronbach's Alpha \\
\hline Metacognitive & 20 & 0.782 \\
\hline Cognitive & 34 & 0.847 \\
\hline Social-affective & 09 & 0.595 \\
\hline
\end{tabular}

To facilitate reporting, responses to the Likert scale were collapsed into dichotomous categories: Less often (never, sometimes) and more often (usually, always).

\section{Results and Discussion}

Contingency analyses to compare the positivity of responses in relation to using the three strategies when listening in class compared with when speaking in class revealed that the outcomes were uniformly significant (Table 4) and that participants who used these three cognitive strategies when speaking in class were likely to do so also when listening in class - though usage was consistently greater when speaking (Figure 1).

\section{Table 4}

Chi Square Tests for Translation, Deduction and Contextualisation by Listening vs. Speaking in Class

\begin{tabular}{|l|c|c|c|}
\hline \multicolumn{1}{|c|}{$\chi^{2}$ Tests } & Value & $\boldsymbol{d f}$ & Asymp. Sig. (2-sided) \\
\hline Translation & 120.518 & 1 & 0.000 \\
\hline Deduction & 101.356 & 1 & 0.000 \\
\hline Contextualisation & 260.155 & 1 & 0.000 \\
\hline
\end{tabular}




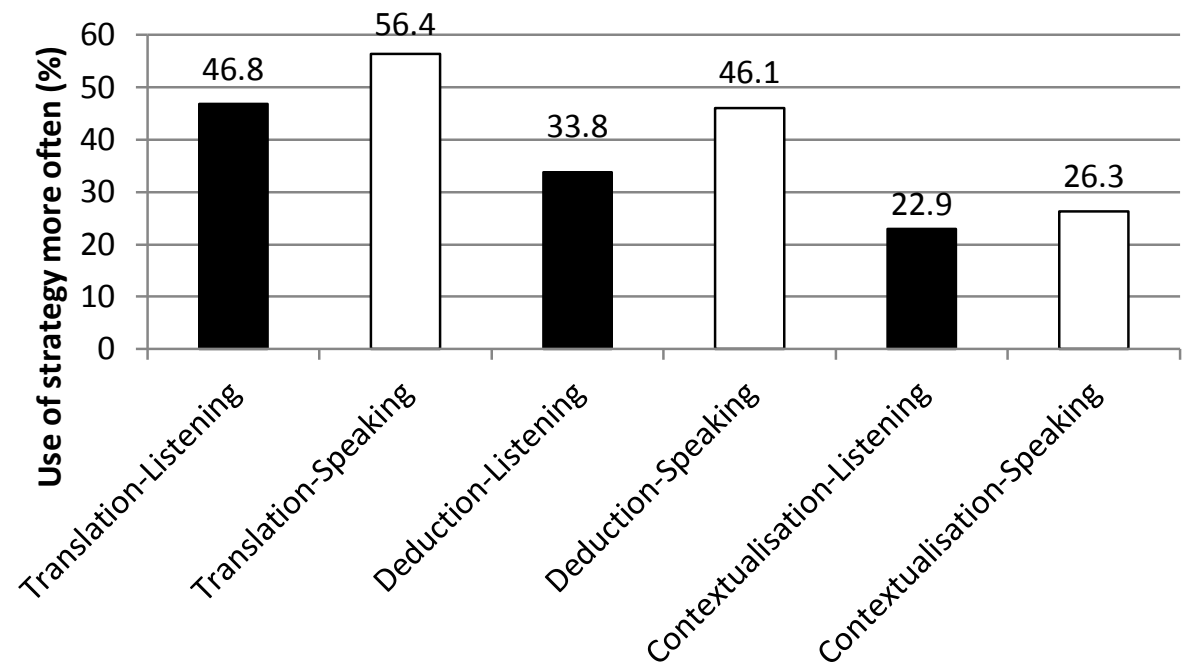

Strategy \& Macroskill

Figure 1. Three cognitive strategies while listening and speaking in class (percent of participants using strategy more often).

Follow-up sign tests (nonparametric related sample) of observed differences in use of translation, deduction, and contextualisation between speaking and listening revealed each of the three sets of differences was statistically significant $(p<.005)$. Regardless of the strategy, cognitive engagement was much greater for learning when speaking.

\section{Table 5}

Sign Test Statistics for Usage Differences of the Three Strategies When Speaking and Listening

\begin{tabular}{|l|c|c|}
\hline \multicolumn{1}{|c|}{ Cognitive Strategies } & Z & Asymp. Sig. (2-tailed) \\
\hline $\begin{array}{l}\text { SC7dich SC7 Translation - } \\
\text { LC6dich LC6 Translation }\end{array}$ & -5.993 & .000 \\
\hline $\begin{array}{l}\text { SC9dich SC9 Deduction - } \\
\text { LC8dich LC8 Deduction }\end{array}$ & -7.667 & .000 \\
\hline $\begin{array}{l}\text { SC12dich SC12 Contextualisation - } \\
\text { LC9dich LC9 Contextualisation }\end{array}$ & -2.801 & .005 \\
\hline
\end{tabular}

The statistical data paint a picture that students use translation, deduction, and contextualisation when listening and speaking in English in and outside their classrooms. In particular, they showed learners made significantly greater use of these strategies in learning-through-speaking tasks. The nature of listening and speaking in Chinese EFL classrooms were re-examined to understand why this might be so, acknowledging the distinction between what have been termed "regular" and "test preparation" classes (Shao, 2006, p. 56). The analysis revealed that in regular classes, there is considerable interactivity between the two macroskills to the extent that these classes were often referred to as "listening and speaking" or "oral communication" classes. As a perusal of the lesson described in Appendix B shows, the two macroskills operate in tandem, and their interaction acts as a scaffold which promotes the development of both skills. For example, the discussion topic 
("College Life") led to group discussions of aspects of the topic which resulted in the cognitive action of arousing and elaborating relevant schemata. These provided the content for top-down processing as the topic and language of discussion developed throughout the course of the lesson (see Breeze, 1998).

This lesson, based around a discussion topic that links directly to discussants' experiences in and beyond the classroom, contrasts with the test-preparation listening lessons that are described in Appendix C. The form of the CET-4 dictates what students will be exposed to in these testpreparation lessons. For a start, no activities require students to exercise their speaking skills. Rather, they receive a number of short conversational exchanges and answer multiple-choice questions on specific information contained in the exchanges. In addition, they listen to monologues and identify specific information. The form of the CET-4 listening test is summarised in Table 6, along with required responses and suggested preparation for the test items.

\section{Table 6}

CET-4 Listening Test with Notes on Required Responses from Students and Student Preparation

\begin{tabular}{|l|l|l|}
\hline \multicolumn{1}{|c|}{ Test items } & \multicolumn{1}{|c|}{ Required Student Response } & Suggested Student Preparation \\
\hline $\begin{array}{l}\text { Section A } \\
\text { Short dialogues }\end{array}$ & $\begin{array}{l}\text { Identify information about daily life } \\
\text { in English-speaking countries }\end{array}$ & $\begin{array}{l}\text { Familiarise with words and } \\
\text { expressions that relate to common } \\
\text { situations }\end{array}$ \\
\hline $\begin{array}{l}\text { Section B } \\
\text { Monologues }\end{array}$ & $\begin{array}{l}\text { Answer specific questions drawn } \\
\text { from monologues }\end{array}$ & $\begin{array}{l}\text { Practise note-taking under stress; } \\
\text { read extensively for general } \\
\text { knowledge }\end{array}$ \\
\hline $\begin{array}{l}\text { Section C } \\
\text { Cloze dictation: monologues }\end{array}$ & Contextualise key points & $\begin{array}{l}\text { Extensive reading to develop } \\
\text { vocabulary, spelling, and writing }\end{array}$ \\
\hline
\end{tabular}

If learners are to be successful in comprehending a spoken text, they first need to activate their topic-related schema. This enables them to access the gist of the text (Vandergrift, 1997). Typically, inside the regular listening classroom, they are provided with the topic of the listening text and perhaps even with specific discussion questions intended to guide them to key words needed in comprehending the spoken text (Appendix B). Consequently, in the early stages of listening comprehension, learners are involved in a working combination of metacognitive and cognitive strategies. The metacognitive strategies contribute through the tactical guidance inherent in such strategies as self-management, selective attention, and self-monitoring, where they provide procedural direction to the cognitive strategies, which are processing techniques such as translation, inferencing, and repetition.

In the beginning of a listening activity, it is likely that metacognitive strategies are particularly important, whereas feedback from listeners' self-monitoring about the sense they are making of a speaker's utterance may signal a shift in balance between the two strategy types - particularly when there is a need to comprehend detail rather than gist (Vandergrift, 1997). Given that in the authors' earlier study (Liyanage et al., 2012), students were finding more opportunities outside to be tactical about their practice in English (i.e., metacognitive procedures were more prominent in outof-class situations than in class), the current finding that they did the same with the cognitive strategies challenges Vandergrift's inference. Seemingly, for these students, the balance was maintained rather than shifted. The authors' interpretation is that the greater operation of metacognitive processing facilitated a more extensive use of translation, deduction, and 
contextualisation in students' larger worlds of listening and learning outside class and in the in-class approximations of those worlds in lessons such as "College Life."

Although participants in the current study identified a range of cognitive strategies to assist listening comprehension, many strategies do not lend themselves to the constraints of real-time listening, in particular if learners are beginners. Listeners are likely to find problems with real-time constraints particularly for the three cognitive strategies under discussion. For example, deduction (involving the application of grammar rules to segments of the spoken text) was found in Vandergrift's (1997) study to be a rather cumbersome way of extracting meaning from the speech stream. In the same study, translation was frequently used (by $13.09 \%$ of listeners) as novice learners attempted to negotiate meaning through the familiar forms of their first language. However, when students discover that reliance on translation may actually impede comprehension by interfering with their attention to what follows in the speech stream (Goh, 2002), they tend to reduce its use severely $(13.09 \%$ to $4.73 \%)$ by the time they achieve intermediate proficiency (Vandergrift, 1997). Current data show similar increases for students' outside-class use of the three cognitive strategies for speaking and for listening. Translation, when used for speaking, becomes a viable tool for an L2 speaker to bridge L1 and L2. Similarly, deduction and contextualisation strategies assist a learner to grammaticalise utterances and to move towards greater precision with spoken L2. Swain (1993) argued that it is this process that leads learners to engage with the language, indeed eventually promoting their accurate use of the L2 grammar.

Because of the nature of the process involved in speaking, learners can exercise greater control than when engaged in listening. For example, the real-time constraints that make listening an extremely difficult and stressful process do not exert the same influence on speaking. Once speakers have successfully bid for their turn and taken it, they are positioned to control a range of communication strategies which may be manipulated to buy time for processing. The positioning provides greater opportunity not only for the processing to occur but also for conscious awareness of the cognition involved. This is not so possible when engaged in listening - where a major part of control resides with the interlocutor - and is less likely in class where a teacher's voice typically is prominent and students are competing for turns. As was theorised in the previous study (Liyanage et al., 2012), when learners are encouraged to discover strategies for themselves, it is likely that these will become an authentic part of their own learning processes.

\section{Conclusion}

The findings in relation to the research question are that the specific cognitive strategies explored translation, deduction, and contextualisation - are used extensively when students are listening and speaking in class. Within the limitations of this study, there are implications for education in these findings. In comparing the listening and speaking lessons in the regular classes (Appendix B) with the test-preparation classes (Appendix C), the authors were struck by the richness and variety of experience to which students are exposed in regular classes compared to that in the extremely narrow and predictable test-preparation classes. Regular classes allowed learners to engage in communication involving the interaction between speaking and listening, where meaning is jointly constructed by co-contributors. In contrast, test-preparation classes are rather one dimensional, with students foregoing interaction as they learn how to comprehend spoken English under examination conditions. This suggests that there are two major objectives that listening and speaking classes need to address in Chinese universities: 
1. To prepare students for oral communication beyond the classroom; and,

2. To prepare students to pass the listening test in the CET-4.

Given the social, cultural, and educational imperatives at play in modern China, there are reasons both objectives must be respected. First, modern China needs an educated workforce of professionals capable of interacting with the rest of the world in the $21^{\text {st }}$ century's lingua franca, English (Seidlhofer, 2001). Second, traditionally, Chinese education has put great store on national examinations due to perceptions that they ensure reliability and therefore equity $(\mathrm{Hu}, 1984)$. For these reasons, it is unlikely that a subject as important as English could be tested in any way other than a national examination, even though the logistics of testing has led to the CET-4 being regarded as having dubious validity as a test of oral English, if for no other reason than the absence of a speaking component for all test takers.

Preparation classes for the listening component of the CET-4 are a product of the washback from the test and as such promote a very narrow, if highly effective, range of learning strategies chosen exclusively for achieving success in the listening test. In contrast, regular listening classes adopt a pedagogy which has been influenced by communicative language teaching (CLT). The approach assumes that since, in practice, listening and speaking skills outside the EFL classroom typically are interactive, then this interactivity should be exploited in the classroom as well (Hinkel, 2006). A perusal of a typical lesson plan for a regular oral communication class (Appendix B) demonstrates a constructivist approach to developing oral communication skills (Crandall, 2000). For example, prior to listening to a comprehension text, students are likely to work in groups to discuss the topic with fellow students and the teacher, or perhaps to read relevant material to activate their schema in preparation for listening to the comprehension passage. Such an approach will yield a range of language learning strategies which are likely to differ both qualitatively and quantitatively from those that are prescribed in the test-preparation classes.

In speaking, the significantly higher use of the three targeted cognitive strategies is at first surprising given that the time over two years officially allocated for speaking (53 hours) is considerably less than for listening (87 hours). However, just as it appeared likely in the previous study (Liyanage et al., 2012) that frequency of metacognitive-strategy use is greater where strategies result from learners' own heuristic efforts, so the more constructivist approach of the regular class may be responsible for learners generating more of their own personalised strategies.

The issues raised in this study about teaching EFL oral communication skills are important for the Chinese context in particular and other contexts within and outside Asia where educational traditions and objectives are conditioned by examination success in general. The study also has highlighted distinctive objectives that drive the teaching of listening and speaking in these contexts, particularly in China. Of interest from this study is that servicing these two broad objectives leads to learners developing two distinctive types of focus for their cognitive learning strategies. Rather than nominate one as superior, it is better to see them for what they are, viz., responses to two different but legitimate educational objectives fashioned by imperatives in response to realities of contemporary Chinese culture and society. To be communicatively competent in modern China is to command the skills, and therefore the learning strategies, necessary to successfully negotiate the public examination system - as well as to interact through English with fellow citizens of a global society. 


\section{Author Note}

Indika Liyanage, Griffith Institute for Educational Research, Griffith University, Queensland, Australia; Brendan Bartlett, Learning Sciences Institute Australia, Australian Catholic University, Queensland, Australia; Thomas Tao, Faculty of Foreign Languages, Beijing Normal University at Zhuhai, People's Republic of China.

Correspondence concerning this article should be addressed to Indika Liyanage, Griffith Institute of Educational Research, Griffith University, Messines Ridge Road, Mount Gravatt, QLD 4122, Australia. E-mail: i.liyanage@griffith.edu.au 


\section{References}

Alderson, J. C., \& Wall, D. (1993). Does washback exist? Applied Linguistics, 14(2), 115-129. http://dx.doi.org/10.1093/applin/14.2.115

Anderson, J. (1993). Is a communicative approach practical for teaching English in China? Pros and cons. System, 21(4), 471-480. http://dx.doi.org/10.1016/0346-251X(93)90058-O

Barlow, T. E., \& Lowe, D. M. (1985). Chinese reflections: Americans teaching in the People's Republic. New York, NY: Praeger.

Bartlett, B. J. (2010). Learning about written language, literacy and meaning: A metalinguistic gift. In M. Raich, P. Schober \& J. Zelger (Eds.), Linguistic structures, theory and practice (pp. 4764). Innsbruck, Austria: Studien Verlag.

Bradshaw, J. (1974). What is language mastery? Audio-Visual Language Journal, 12(3), 129-133.

Breeze, R. (1998). EFL pairwork: Ethnographic and neo-Vygotskian perspectives. Atlantis, 20(2), 516.

Chamot, A. U., Kupper, J. L., \& Impik-Hernandez, M. V. (1987). A study of learning strategies in foreign language instruction. First year report. Retrieved from ERIC database. (ED352824)

Cortazzi, M., \& Jin, L. (1996). Cultures of learning: Language classrooms in China. In H. Coleman (Ed.), Society and the language classroom (pp. 169-206). Cambridge, UK: Cambridge University Press.

Crandall, J. (2000). Language teacher education. Annual Review of Applied Linguistics, 20, 34-58. http://dx.doi.org/10.1017/S0267190500200032

Goh, C. C. M. (2002). Exploring listening comprehension tactics and their interaction patterns. System, 3a(2), 185-206. http://dx.doi.org/10.1016/S0346-251X(02)00004-0

Harvey, P. (1985). A lesson to be learned: Chinese approaches to language learning. ELT Journal, 39(3), 183-186. http://dx.doi.org/10.1093/elt/39.3.183

Hinkel, E. (2006). Current perspectives on teaching the four skills. TESOL Quarterly, 4O1), 109131. http://dx.doi.org/10.2307/40264513

$\mathrm{Hu}, \mathrm{C}$. T. (1984). The historical background: Examinations and control in pre-modern China. Comparative Education, 201), 7-26. http://dx.doi.org/10.1080/0305006840200103

Jin, Y. (2008). Powerful tests, powerless test designers? - Challenges facing the College English Test. English Language Teaching in China, 31(5), 3-11.

Lin, J. S. (2009). Washback of English examination on English teaching and learning in China. Paper presented at the Graduate Faculty, University of Wisconsin-Platteville in partial fulfilment of the requirement for the degree Master of Science in Education.

Liyanage, I. (2004). An exploration of language learning strategies and learner variables of Sri Lankan learners of English as a second language with special reference to their personality types. Unpublished doctoral dissertation (Ph.D.), Griffith University, Brisbane, Queensland, Australia.

Liyanage, I., \& Bartlett, B. J. (2010). From autopsy to biopsy: A metacognitive view of lesson planning and teacher trainees in ELT. Teaching and Teacher Education, 26(7), 1362-1371. http://dx.doi.org/10.1016/j.tate.2010.03.006

Liyanage, I., \& Bartlett, B. J. (2012). Gender and language learning strategies: Looking beyond the categories. Language Learning Journal, 40(2), 237-253.

http://dx.doi.org/10.1080/09571736.2011.574818

Liyanage, I., Bartlett, B. J., Birch, G., \& Tao, T. (2012). "To be or not to be" metacognitive: Learning EFL strategically. Electronic Journal of Foreign Language Teaching, 9(1), 5-25. Available at http://e-flt.nus.edu.sg/v9n12012/liyanage.pdf 
Liyanage, I., Grimbeek, P., \& Bryer, F. (2010). Relative cultural contributions of religion and ethnicity to the language learning strategy choices of ESL students in Sri Lankan and Japanese high schools. Asian EFL Journal, 12(1), 165-180.

Maley, A. (1983). XANADU-A miracle of rare device: The teaching of English in China. Language Learning and Communication, 2(1), 98-104.

O'Malley, J. M., \& Chamot, A. U. (1990). Learning strategies in second language acquisition. Cambridge, UK: Cambridge University Press. http://dx.doi.org/10.1017/CBO9781139524490

Oxford-Carpenter, R. (1985). A new taxonomy of second language learning strategies. Washington, DC: CAL/ERIC Clearinghouse on Languages and Linguistics.

Peng, J. (2007). Willingness to communicative in the Chinese EFL classroom: A cultural perspective. In J. Liu (Ed.), English language teaching in China: New approaches, perspectives and standards (pp. 250-269). London, UK: Continuum.

Rao, Z. (2002). Chinese students' perceptions of communicative and non-communicative activities in EFL classroom. System, 301), 85-105. http://dx.doi.org/10.1016/S0346-251X(01)00050-1

Scovel, T. (1983). The impact of foreign experts, methodology and materials on English language study in China. Language Learning and Communication, 2(1), 83-91.

Seidlhofer, B. (2001). Closing a conceptual gap: The case for a description of English as a lingua franca. International Journal of Applied Linguistics, 11(2), 133-158. http://dx.doi.org/10.1111/1473-4192.00011

Shao, H. (2006). An empirical study of washback from CET-4 on college English teaching and learning. CELEA Journal, 29(1), 54-60.

Swain, M. (1993). The output hypothesis: Just speaking and writing aren't enough. Canadian Modern Language Review, 501), 158-164.

Tan, Z. (2008). Questioning in Chinese university EFL classrooms: What lies beyond it? RELC Journal, 38(1), 87-103. http://dx.doi.org/10.1177/0033688206076161

Vandergrift, L. (1997). The comprehension strategies of second language (French) listeners: A descriptive study. Foreign Language Annals, 30(3), 387-409. http://dx.doi.org/10.1111/j.1944-9720.1997.tb02362.x

Wang, W. (2010). Investigating the washback effect of the new CET-4 listening comprehension subtest on language learners. Chinese Journal of Applied Linguistics, 33(5), 28-39.

Wang, Y. (1991). Teaching oral English: Problems and solutions. ELIC Teaching, 8, 31-34. 


\section{Appendix - A \\ Adapted Language Learning Strategy Inventory (LLSI) \\ (Liyanage et al., 2012)}

Note: For reasons of space, the presentation here does not correspond to that of the actual questionnaire. In particular, the numbers $1-2-3-4$ appeared under each item to enable participants to record their scores.

\section{Instructions}

Students sometimes have special ways of studying - ways that help them learn another language. We want to know about the different things you do when you learn English. On the following pages you will find statements about learning English. Please read each statement, and circle one number $(1,2,3$, or 4$)$ to indicate if the statement is:

1. Almost Always true of you [76-100\% of the time]

2. Usually true of you [51-75\% of the time]

3. Sometimes true of you $[26-50 \%$ of the time]

4. Almost Never true of you $[0-25 \%$ of the time]

There are no right or wrong answers. Your answers will only describe what you do. The following example shows how you should answers the questions on the following pages.

\section{Example}

Read the example below and draw a circle around the number that tells how often you do the behaviour described:

I write down any new words, phrases or rules my teacher says.

1 (Always) 2 (Usually) $\quad 3$ (Sometimes) 4 (Never)

If you almost always write down new words your teacher says, circle number 1. If you usually write down new words, circle number 2. Similarly, if you sometimes do this, circle number 3, and if you never do this, you would circle number 4.

A short paragraph at the top of each page describes the scenario in which each statement occurs. 


\section{Scenario}

\section{Listening in class}

In a typical class period your teacher uses English to: give directions, explain new material or review old material, and to ask the class questions.

(1) When I listen, I plan in advance to pay more attention to what the teacher is going to talk about in general than to specific words and details.

(2) I write down any new words, phrases or rules my teacher says so I'll be sure to remember them.

(3) I ask the teacher questions when I don't understand what he or she is saying.

(4) When I hear a new English word, I try to learn the teacher's pronunciation by copying or imitating it.

(5) When I hear a new English word that sounds like a familiar Chinese word, I assume it has a similar meaning.

(6) I find myself translating what the teacher says back into Chinese so I can understand.

(7) When I learn a new word or phrase, I play it back in my mind to remember it.

(8) When listening to the teacher, I apply grammar rules to help myself understand.

(9) When I hear a new word, I think of a sentence in which I might use it later.

(10) When I don't understand what the teacher says, I get help from a classmate.

(11) I try to relate what I'm hearing to my own experiences or to information I already know.

(12) I guess at the meaning of unfamiliar words by using my knowledge of prefixes and suffixes.

(13) I pay more attention to some words and phrases than to others when the teacher is talking in English.

(14) After I listen, I try to summarise mentally what the teacher says to understand it better.

\section{Scenario}

\section{Speaking in class}

The teacher requires class participation. This means that you have to speak English in class, including asking and answering questions, participating in oral drills, reading aloud and perhaps giving a short oral presentation.

(1) When the teacher calls on me in class, I plan my answer in my head before I say a word.

(2) I listen carefully to what I say and correct myself when I make a mistake.

(3) If I have to give a talk to the class, I present it to a friend first so he or she can tell me how it sounds.

(4) If I have to give a talk to the class, I practise the talk several times paying attention to the meaning of the talk before I actually do it.

(5) If I have to give a talk to the class, I mentally practise the talk before I actually do it to reduce anxiety.

(6) If I can't recall a word or phrase when I speak in English, I try to use another word or phrase to replace it.

(7) I think in Chinese of what I want to say and then I translate it into English.

(8) When I speak, I am generally unaware of any mistakes I might be making.

(9) I consciously apply grammar rules when I speak English.

(10) I volunteer answers in class so I can practice using English.

(11) I try to answer all questions mentally, even when the teacher is addressing someone else.

(12) When I learn a new word, I say it in a sentence as soon as possible. 


\section{Scenario}

\section{Listening and speaking outside of class}

You have an opportunity to speak English outside of class. For example, you meet several native speakers of English.

(1) I listen especially for words or phrases that I already know to help me understand what is going on in a conversation.

(2) I talk about the same sorts of things in English that I talk about in Chinese.

(3) I ask native speakers the correct way to say things.

(4) I try to talk with native speakers and keep the conversation going, because I get more practice that way.

(5) If I don't completely understand what the other person says to me, I think about the words I did understand and try to guess what he or she might be saying.

(6) I relate the English I hear in conversations to what I've learned in class.

(7) If I don't understand what the other person says to me, I ask them to speak more slowly or to say it in a different way.

(8) When I know I'm going to be around native speakers, I plan a few things to say.

(9) I go home afterwards and think about what I said to see if I made any mistakes.

\section{Scenario}

\section{Reading in English}

The teacher assigns a reading selection for homework. This may be a short story or an article from a newspaper, or a cultural passage.

(1) Before I read, I plan to pay more attention to the general meaning of the passage than to specific words, phrases and details.

(2) Before I actually read (a passage or book), I arrange myself a treat to enjoy on completion of the task.

(3) When I find the meaning of a new word, I read it over and over again to remember its meaning.

(4) I take notes when I read, listing the new words or phrases I find in the passage.

(5) I scan for special words, phrases or information to get the most important points when I read.

(6) When I read, I organise information under different headings according to their attributes.

(7) I try to guess the meaning of unfamiliar words by looking at the words in the rest of the sentence.

(8) I get the major ideas of a reading selection by checking the comprehension questions before I begin reading.

(9) When I read, I try to visualise what I read.

(10) I first skim the material I must read to get the main idea and concepts.

(11) I practice my reading skills by trying to read extra materials in English (such as newspapers, magazines, ads, etc).

(12) When I read new words, I think of what other situations they might be used in.

(13) I try to relate what I'm reading to my own experiences or to material I already know.

(14) I use a monolingual dictionary (English) to understand additional meanings of the words I read.

(15) After I finish reading, I check my understanding by seeing if I can remember the main ideas of the passage.

(16) After I finish reading, I try to summarise mentally what I have read to understand it better. 


\section{Scenario}

\section{Writing in English}

The teacher has assigned a short composition or paragraph to be written entirely in English. This might be to write a report or to describe a picture or a personal experience.

(1) Before I actually do a writing task (e.g. writing an essay or a letter) I arrange myself a treat to enjoy on completion of the task.

(2) I use what I know about writing in Chinese (structure. organization, etc) to help write in English.

(3) Before I write the actual assignment, I write a few drafts to see whether it conveys the intended meaning.

(4) When I write, I replace words and phrases that I can't recall with other words or phrases that have the same meaning.

(5) I write the assignment first in Chinese, and then translate it into English.

(6) I consciously use grammatical rules when I write in English.

(7) For accuracy, I ask a friend to read over what I've written.

(8) I use a monolingual (English) dictionary or other English reference materials when I write in English.

(9) I use my textbook and dictionary to look up spelling, verb conjugations, and gender agreement, etc.

(10) I carefully reread what I've written to make sure there are no mistakes.

(11) Before writing, I make a plan or outline of what I want to say.

(12) While writing a first draft, I try to get all my ideas down instead of worrying about spelling and grammar. 


\section{Appendix B \\ An Outline of a Listening and Speaking Class}

Reflection by a teacher at a Chinese normal university of a listening and speaking class he has taught to a group of freshmen.

This is a reflection on a listening and speaking class I have given and a summary of the experience I have gained from it. I will illustrate the teaching strategies I employed and the process I went through in the process of preparing the lesson.

The topic for the lesson demonstrated below is College Life, and a tape script for the lesson is attached for reference. The textbook I used was New Horizon College English Viewing, Listening \& Speaking published by Foreign Language Teaching and Research Press, and the students were non-English major freshmen. To instruct the lesson, I worked out a plan as follows.

Time Allotment: 2 periods (90 minutes)

Teaching Objectives:

- To help students practice the listening skill of Focusing on Details

- To help students practice the listening skill of General Comprehension

- To familiarize students with English expressions to describe various aspects of college life

- To help students talk about college life freely in English

Lesson Content:

1. Warming-up Discussion:

- Introduce the topic, divide students into 4 groups to discuss different aspects of college life, and assign a sub-topic to each group.

Group 1: Study (e.g., course selection, registration, major, tuition, and scholarship, etc.) Group 2: Living on campus (e.g., living in a dorm, food, shopping, and commuting to class, etc.)

Group 3: School facilities (e.g., stadium, swimming pool, library, dining hall, and labs, etc.)

Group 4: Extracurricular activities (e.g., associations, part-time jobs, and parties, etc.) (10 minutes)

2. Observe the discussion, check students' vocabulary and introduce new words and expressions that may help them better explain their ideas. (5 minutes)

3. Finish Exercises Part 2 and Part 3 in the textbook. Exercise Part 2 helps students to practice the listening skill of focusing on details, while Part 3 aims to improve students' general comprehension. (35 minutes)

4. Oral Practice:

- $\quad$ Finish Exercise Part 4. This exercise helps students to speak out some of the expressions they have just heard in the listening practice.

- Further consolidate students' mastery of the expressions and sentence structures they have learned by some classroom activities: 
i. Create Stories: One student begins a story like "I enjoy college life because living in a dorm with some friendly peers is fantastic. I went to the swimming pool with my roommates yesterday ...." Then another student continues with one or two sentences. Students are required to keep the story relevant to the topic College Life and use as many expressions they have learned as possible.

ii. Debate: Divide students into groups to debate over controversial issues in college life. Suggested topics for the debate include:

$\checkmark \quad$ Which is a better choice, living on campus or living off campus?

$\checkmark \quad$ What is more important, study or extracurricular activities? (25 minutes)

5. Comment on students' performance. If time permits, finish Exercise Part 5 (Further Listening and Speaking). (15 minutes)

6. Assignment: Ask students to review the language points after class and prepare for a quiz next class.

Notes:

Generally speaking, I instruct in a topic-oriented way. This is partly because the textbook is compiled in much the same way. I would identify a topic for each class beforehand, work out key words and expressions relevant to this topic, anticipate students' vocabulary and knowledge, and then search for information that I could complement in class.

The next step is to find out students' real understanding of the topic and their language proficiency. This is usually done by a warming-up discussion at the beginning of the class and a careful observation of the discussion. From the observation, I know what the students already master and what they don't know, and this helps me to provide them with something they really need.

After the warming up, students are equipped with basic vocabulary and knowledge to deal with the listening exercise in the textbook, which consists of gap-filling and short-answer questions to help them practice two listening skills that are mentioned in the lesson plan above.

As is known to all, listening and speaking are intertwined. If we compare the former to a kind of input, then the latter is output. To improve students' oral English, it is vital to help them speak out what they've heard as soon as possible. This is why the focus of the class shifts to speaking in the second session. In this session, apart from doing speaking exercises in the textbook, students are encouraged to participate in classroom activities to practice words, expressions and sentence structures they've learned.

Finally, to test the effectiveness of the above-mentioned teaching strategies, a quiz would be given in the following class to check students' command of language skills and knowledge they are expected to master. 


\section{Appendix B \\ An Interview with a Teacher of a CET-4 Preparation Class Regarding Listening Comprehension Test Preparation}

1. What (in detail) is the format of the listening comprehension test?

A typical example to illustrate the format is the listening test in CET-4 (College English Test Band 4) or CET-6 (College English Test Band 6), a nationwide test to examine students' English proficiency in China. The test consists of eight short conversations, two long conversations, three short passages for multiple-choice questions, and one passage for dictation.

2. How does this affect what teachers do in preparing the students for this test?

Different sections in the test pose different challenges to students. For example, conversations in Section A reflect all kinds of topics and situations students may encounter in their daily life. Thus, this section tests students' familiarity with English expressions used in daily communication. To prepare students for this part, teachers should help them identify various situations in daily life and summarize key words and expressions frequently used in these situations. Section B consists of three passages, which take the form of monologue or lecture and cover topics like politics, economy, history, culture, education, health, science, and technology. When it comes to the listening skill tested in this part, it is students' ability to pinpoint the information they need to answer the questions. Therefore, teachers should teach students techniques to anticipate needed information from the questions and take down the information quickly and correctly by means of shorthand. Meanwhile, to help students better understand the passage, they should encourage students to read extensively after class to gain background knowledge in various areas. Section C tests not only students' listening comprehension, but also their spelling and writing skills. Therefore, vocabulary, spelling, and grammar should be stressed in this part. 